Portland State University

PDXScholar

$1-1-2013$

\title{
Exploring Realism and Magical Realism in Slum Novels of the Global South
}

Benjamin Hawkins

Portland State University

Follow this and additional works at: https://pdxscholar.library.pdx.edu/honorstheses Let us know how access to this document benefits you.

\section{Recommended Citation}

Hawkins, Benjamin, "Exploring Realism and Magical Realism in Slum Novels of the Global South" (2013). University Honors Theses. Paper 6.

https://doi.org/10.15760/honors.6

This Thesis is brought to you for free and open access. It has been accepted for inclusion in University Honors Theses by an authorized administrator of PDXScholar. Please contact us if we can make this document more accessible: pdxscholar@pdx.edu. 
Exploring Realism and Magical Realism in Slum Novels of the Global South

\author{
by \\ Benjamin Hawkins
}

An Undergraduate Honors Thesis Submitted in Partial Fulfillment of the

Requirements for the Degree of
Bachelor of Arts
in
University Honors
and
English

Thesis Adviser

Dr. Bishupal Limbu

Portland State University

2013 
Exploring Realism and Magical Realism in Slum Novels of the Global South

In literature, who can speak for oppressed communities? Can authors write about a peoples' experience without imbuing their own cultural perspective into the mouths of their characters? Can an author represent the complexities of a marginalized community without being reductive? Or disrespectful? Or oppressive? These are questions that have no definitive answer, other than "it depends". It depends upon the author's background, it depends upon the community being depicted, it depends upon the motivation for that depiction, it depends upon the audience, it depends upon the critic: it is a complex question which depends upon many variables. I'm interested in one particular variable, because its assertion wipes out consideration for the others. It deals not with who should be writing, but how one should write. Hande Tekdemir in her article "Magical Realism in the Peripheries of the Metropolis" writes the following when comparing two "magic" novels Berji Kristin: Tales from the Garbage Hills by Latife Tekin and Tropic of Orange by Karen Tei Yamashita: "Both novels, as do most magical realist texts. . .react against the realist novel tradition that tends to only represent Western reality" $(41)^{1}$. Since such an essentializing statement regarding authenticity is rare in postcolonial literature studies, it warrants a closer look. First, to gain some traction on this assertion we must have an understanding of the critical and historical climate in which Tekdemir defines her understanding of magical realism, and the realist tradition.

\footnotetext{
${ }^{1}$ Tekin's novel is spelled both Berji Kristen and Berji Kristin. I use the latter spelling in this paper.
} 


\section{Realism and its Discontents}

Realism as a mode came to dominance in the $19^{\text {th }}$ century alongside the emergent secular epistemologies of the enlightenment (Morris 9). It borrows from the scientific traditions the view that reality (physical, objective, as well as subjective) can be known and represented. Realism is inherently ideological as its comprehensibility is predicated upon the reader's acceptance of certain philosophical ground rules which the critic lan Watts explains succinctly enough. "Modern realism begins from the position that truth can be discovered by the individual through his sense ... the external world is real and our senses give us a true report of it" ( qtd. in Bowers 21). Underlying realism's aesthetic assumptions is the concept of mimesis, the idea of art as a reproduction of some external reality (Morris 5) which dates back to Aristotle's Poetics ${ }^{2}$. This is not to say that a realist writer's goal is to present a mirror to reality or to write a world with language that bears a one-to-one correspondence to the experience outside the text (Morris 4). Such an approach cuts out an avenue for artistic creativity, whch allows the selective ordering of experience, which "entail[s] the values and perspective of the describer" (4). Also, such a transcription is impossible. Language bears a uniform looseness in relation to reality so no matter one's register, words are not the objects they describe and are associated with. As Terry Eagleton says "the relationship between language and reality is not a

\footnotetext{
${ }^{2}$ “Since a poet represents, just like a painter or some other maker of images, at any moment he is necessarily representing one of three things, either (a) things as they were or are, or (b) things as people say and think [they were or are], or (c) things as they should be" (Poetics 111). However prescriptivist Aristotle's poetics may seem, he leaves room for the representation of the 'impossible'. Although it is always phrased as an error to create "impossibilities" in artistic representation, it is a "good error" if it furthers the goals of the art and an incorrect error if "the end [of the art] could have been brought about better or no worse" without the departure (111).
} 
spacial one" (4). The use of language to describe the world is inherently creative, therefor realist attempts at similitude in their work are inescapably artistic enterprises, unique to the author's self and perspective.

Although seriously questioned during modernism and postmodernism, key elements of realism have persisted in the novel, most remarkably in that most novels seek to make some contribution to their understanding of reality. Though the means of this pursuit were aesthetically contested by modernists and postmodernists, they too intended their novels to communicate knowledge, believing that they had the ability to do so (Morris 17). Realism is a genre in flux aesthetically and philosophically, which allows it to stay relevant and dominant. The same is the case for all surviving modes. As Pam Morris observes "literary genres do not stand still: to remain vibrant they adapt to the changing social realities within which they are produced" (32). Realism creates new aesthetics to communicate understanding of the world's physical and subjective components while remaining interested in discovering and transmitting that knowledge.

The mode's concern for reality draws it to depict society in all its depravity and grotesquery. This penchant for social commentary has been carried through the mode's history by authors who share a concern for illuminating the extent of stratification in their societies, often (especially in Dickens' case) raising public awareness of social injustice and ultimately inspiring legislative action (Diniejko).

But, while often claiming to be humanistic in motivation, many realist accounts of the colonial world took for granted their supposed objective viewpoints, creating representations that reflect the racist assumptions and justifications for colonialism. Literature has the power to 
create and reinforce the cultural perceptions of European superiority and indigenous "otherness" that were essential to the colonial project (Loomba 66). Since realism was the predominant mode during the height of colonial era, the genres' implicit claim to truth seems especially suspect, if not toxic to many postcolonial critics. Depictions of colonized people as subhuman savages abound in literature of the colonial period, alongside softer but no less disenfranchising images of the indigenous as misguided children who need the civilizing forces of Europe to raise them out of darkness (see Kipling's "White Man's Burden" or Haggard's King Solomon's Mines ). Canonical western works were used as oppressive ideological weapons against colonized people by perpetuating a picture of dark people as inferior, while simultaneously denigrating indigenous methods of cultural production ${ }^{3}$. What was thought of as a civilizing mission was an attempt to demonstrate the "authority of English and European culture" by teaching the "authority" of European literature over indigenous art (Loomba 78).

Given its checkered past, it is unsurprising that realism is viewed suspiciously by many postcolonial scholars as an intrinsically oppressive form. Magical realism in Tekdemir's estimation, is an authentic mode, even a decolonizing one, directly oppositional to western cultural domination.

\footnotetext{
${ }^{3}$ Macaulay's notorious "Minute on Indian Education" comes to mind here: "I have no knowledge of either Sanscrit or Arabic. But I have done what I could to form a correct estimate of their value. I have read translations of the most celebrated Arabic and Sanscrit works. I have conversed both here and at home with men distinguished by their proficiency in the Eastern tongues. I am quite ready to take the Oriental learning at the valuation of the Orientalists themselves. I have never found one among them who could deny that a single shelf of a good European library was worth the whole native literature of India and Arabia. The intrinsic superiority of the Western literature is, indeed, fully admitted by those members of the Committee who support the Oriental plan of education"
} 
Magical Realism

Tekdemir describes magical realism as a style that traditionally emphasizes the communal over the individual, a form that allows for events that from a materialist standpoint could not happen in realist fiction: it creates space in its representation for the fantastic to enter the world in "matter-of-fact" assimilation (Tekdemir 42). In the preface to Magical Realism: Theory, History, Community (a preface also cited in Tekdemir's article) editors Lois Parkinson Zamora and Wendy B. Faris articulate an essential aspect of the form's popularity: "Indeed we may suppose that the widespread appeal of magical realist fiction today responds . . . to its impulse to reestablish contact with traditions temporarily eclipsed by the mimetic constraints of nineteenth and twentieth century realism" (2). Magical realism is seen by some critics as a link to representational traditions uprooted by the western cultural intrusions that were part and parcel of colonialism, specifically the realist novel. While third world and postcolonial nations are unable to turn back the clock on western cultural imperialism regardless of what mode of representation authors use, magical realism can be made to reflect the cultural experience of marginalized communities, and interrupt Western hegemonic views on representation. Amaryll Chanady describes the mode as more tolerant than realism due to its "absence of obvious judgments about the veracity of events and authenticity of the world expressed by characters in the text" (qtd. in Bowers 4). This absence of judgment opens the door for more diverse depictions of reality that fall outside the Western empirical view of what can be experienced.

The mode's tolerance is perhaps better expressed as flexibility. Magical realist texts construct their reality within the traditions of the culture and community the writer is drawing 
from, making the representation of the extraordinary unique to discrete culture groups. The "magic" in magical realist mode has as many unique manifestations as there are cultural contexts (Bower 4). The mode's formative connection to the faith and stories of communities is what separates it from other modern schools like surrealism, because rather than deriving a dogmatic poetics from polemical manifestos, magical realism preserves an open interpretation of itself, contributing to its flexibility and adaptability to unique contexts worldwide.

There is extensive criticism on the power of magical realism to upset the western hegemonic views used or implied in realism ${ }^{4}$. Often overlooked are the ways in which realism is used by magical realism. Many seem to forget that the last half of the term refers to a specific mode for a reason. Magical realism uses realism to provide an environment with which to stretch the reader's notions of what is acceptable as reality (Bower 22). It is a hybridized form, appropriating the western cultural institution of the realist novel as a context from which to represent unacceptable (often indigenous) understandings of the world within comfortable western value systems. The effect is to normalize the magical, correspondingly disturbing the epistemological order of the Western dominated world. Magical realism needs realism to frame real, imagined, or magical events as reality. The seamless interweaving of realist and magical elements that defines the style is dependent upon the mixing of these modes.

\footnotetext{
${ }^{4}$ Theo L. D'haen describes magical realism's ability to produce texts from outside Western tradition that are not from the "privileged centers" associated with realism, modernism and postmodernism, but still able to comment on and "correct" western reality (qtd. in Zamora 195). Zamora calls Magical realism "truly postmodern," that its "counterrealistic conventions" can widen our conception of ourselves. She particularly focuses on magical realism's tendency to "universalize the self" against more modern narratives that elevate the individual (qtd. in Magical Realism 498).
} 
I agree that magical realism is more closely affiliated with certain non-Western cultural values. However this doesn't mean that realism cannot attend to the experience of nonWestern communities with its own resources. I argue that in novels dealing expressly with survival in a hostile urban environment, the physical experience of marginalized communities can be represented in the realist mode and may even more dramatically depict it at times. While I acknowledge that the realist elevation of the individual may take some focus off the community itself, it can also help the reader empathize with the character's experience, which in these novels is taken at some level to be a synecdoche for the community.

Above all, to imply that the magical realist mode is inherently better at giving voice to such communities is reductive on two levels: 1 ) it romanticizes magical realism as an agent of decolonization and as unconditionally more authentic than realism, which puts unfair and unrealistic expectations on the mode and the authors who write in it; 2) it elides the many possibilities offered by realism. While Tekdemir and others seem to believe that magical realism is the only appropriate mode of representation for communities in these circumstances, I believe communities need the capabilities of both magical realism and realism to dramatize their experiences.

To prove my last point I will be examining the magical realist Berji Kristin with GraceLand, a novel done in the realist mode. Both depict the lives of slum communities existing precariously on the edge of metropolises in the global South. In Berji Kristin the slums known as The Garbage Hills (for their location on dumping grounds) are in the periphery of Istanbul. Here migrant workers and their families fight for work and a clean biosphere with exploitative factory owners who pollute the water and air. Graceland shows the lives of the poor in the slums of 
Lagos, Nigeria, where the indigent are pitted against local elites who work together with Western imperialism to exploit their own people. Both novels depict a polluted ecosystem in which the residents must live and work, one that paradoxically allows life just as it attritionally degrades it through exposure to toxified water, air, and land. To understand how these novels make real the desperate ecological situation marginalized communities are in, I will be examining the texts through the critical lens of Rob Nixon's book Slow Violence and the Environmentalism of the Poor. In his book, Nixon coins the term "slow violence" to describe the pain, suffering, and death inherent in the environmental toxification of living spaces. "Slow" encapsulates the attritional and gradual nature of many of these phenomena which obscures understanding of the origin and causes of violence. Moreover, the unspectacular and longlasting nature of slow violence is less visible and therefore often not viewed as violence at all. When competing with other forms of suffering and disaster for media attention, slow violence often loses because it lacks the decipherability and drama of the more immediate varieties. The challenge of depicting this violence lies in overcoming the obscurity in which it takes place.

Real world examples of slow violence are sadly prevalent and disproportionally attached to the global South: the continued pollution of the Niger River delta by Shell and Chevron through reckless oil prospecting, the 1984 chemical explosion at the Union Carbide plant in Bhopal, and the millions of radioactive depleted uranium shells deployed in the Gulf War. In addition to the high human cost of ecosystem toxification, what these disparate environmental catastrophes have in common are their unclear temporal and spacial boundaries, that is to say, their duration and radius of destruction. A gunshot has a clear cause and effect. It has a beginning and an end, a clear murdered and murderer. For narrative purposes, this event is 
relatively easy to effectively portray. One can find out who has shot and who has been shot, and from there begin to infer motive if it is not obvious. The lines of causality are clearly drawn. Slow violence maims and kills just as undeniably, but not as recognizably or obviously, because it lacks the defined time and space restrictions more apparent violence has.

Toxic practices like dangerous and exploitative oil prospecting in the Niger Delta (where the equivalent of an Exxon Valdez sized oil spill occurred annually for nearly half a century [Nixon, "Slow Violence and Environmental Storytelling"]) produces casualties in multiple temporal zones. Shell and Chevron's oil harvesting had the support of the Abacha government which ran a campaign of murder, torture, and intimidation to suppress indigenous peoples' environmental rights movements. The 2,000 indigenous Ogoni killed by 1995 (Slow Violence 107) provide the easiest casualty number to attach to the tragedy. However, such a figure is misleading. The true toll is unknown because the violence continues as unrecovered oil continues to seep into farm land and the water table, poisoning agriculture, drinking water and fishing grounds (107). In Niger Delta communities where subsistence agriculture and fishing are the main modes of survival, such ecological destruction negatively impacts generations by reducing the productivity of their natural resources while causing health issues for locals who "have to drink, cook with and wash in polluted water, and eat fish contaminated with oil and other toxins" (Amnesty International). Authors wishing to show the hidden pervasiveness of the effects of slow violence on communities must contend with the expansive duration and radius of destruction that often surpass the original event.

Sociological texts such as Mike Davis' Planet of Slums work to identify the hidden causes and effects of slow violence, and I will use them to give some quantitative understanding of the 
slum life in the Lagos of GraceLand. But as Nixon writes, social scientific takes on the global poor, while useful in certain contexts, run the risk of reducing them to anonymous statistics: swallowing up the human story in favor of a strictly analytical approach (66). As Nixon points out "such accounts thus tend to be in the same gesture humanizing and dehumanizing, animating and silencing" (66). Depicting the precarious humanity of marginalized communities is therefore a job for storytellers.

Although the two novels work in different modes, GraceLand and Berji Kristin have the power to dramatize the pervasive effects of slow violence, an essential piece of the experience of marginalized communities'. I'm interested in how the novels' differing modes overcome the narrative and representational challenges posed by this kind of violence. What follows is an examination of differing realist and magical aesthetic approaches to dramatizing ecological degradation and the precarious lives that survive (or don't) in toxic urban environments.

GraceLand by Chis Abani, centers upon a young protagonist named Elvis, who lives in the slums of 1983 Lagos with his father and step-family. While In the process of launching his dancing career, Elvis' experiences in the city's grimy underbelly reveals toxic corruption among the nation's elites as well as the West's exploitative relationship with Nigeria. Reflecting upon his family's arrival in Lagos, Elvis describes a side of the metropolis hidden from view. "He hadn't known about the violence and poverty of Lagos until he arrived. It was as if people conspired with the city to weave a web of silence around its unsavory parts" (7). When these "unsavory parts" are shown, they are depicted in scenes shocking in their destitution, yet made all the more effective by the sparse prose in which they are written. The following passage is a description of Elvis' neighborhood, the slum called Maroko: 
As he left the buka and walked to the bus stop, Elvis realized that nothing prepared you for Maroko ... As he looked, a child, a little boy, sank into the black filth beneath one of the houses, rooting like a pig. Elvis guessed it was some form of play. To his left, a man squatted on the plank walkway outside his house, defecating into the swamp below, where a dog lapped up the feces before they hit the ground. Elvis looked away in disgust and saw another young boy sitting on an outcrop of planking, dangling a rod in the water. (48)

This passage shows a twisted food web, the perverted ecosystem in Elvis' community where the environment is fouled by overuse and lack of sanitation facilities. Yet the residents have no choice but to continue to fish from the sewer-swamp and drink from its contaminated waters. The conditions portrayed in this scene are unbelievable, but perfectly accurate. In Nigeria's urban areas, those living in extreme poverty (defined by the World Bank as individuals surviving on $\$ 1.25$ or less per day) have grown from 28 percent in 1980 to 66 percent in 1996, creating slums so destitute that outside observers don't know how the poor survive (qtd. in Dawson 17). Crushing poverty in densely populated areas combined with nonexistent sanitation services create a hazardous environment for much of the poor in Lagos. Nigeria as a whole lacks access to basic sanitation for 33 million of its people and in the slums of Lagos the lack of infrastructure endangers the health of 70 percent of the city's 11.2 million estimated residents, especially infants and toddlers (Ibukun). This is where Abani's realist depiction shows its strength in representing the horrifying state of affairs for the poor. The unbelievability of the community's experience is phrased in terms that cannot possibly be interpreted as only metaphorical. There is room to interpret the depiction that way, but the passage will not let the reader escape the 
unsettling scene through an interpretation that would mark it as figurative or a fantastical account.

Paradoxically, the realist approach to depiction in GraceLand often inspires horror and revulsion associated with melodramatic genres such as Gothic literature. As Lawrence Buell suggests, "The more toxic discourse focuses on individual cases, the more readily toxic discourse montages into the Gothic" (653). Buell is writing about American accounts of poisoned living space, referencing Rachael Carson's Silent Spring in particular, but the concept certainly transfers to Abani's fiction. Because the inhabitants of Maroko have no choice but to partake of tainted resources, their struggles seem all the more grotesque. Where people struggle to feed themselves on a daily basis, one is lucky to catch a fish out of a sewer.

Graceland succeeds in dramatizing unfathomable living conditions to the reader not only because of its bare, matter-of-fact language, but also due to Abani's choice of protagonist. Elvis, though he is Nigerian, is an outsider in the slum of Maroko. As an outsider his lack of experience with the horrors of slum life influences what he sees and what he focuses on. His naiveté in matters of survival makes it easy for readers to identify with him. Since he seems to be more horrified by the depravity of Maroko than the other residents, he is an ideal choice as the reader's tour guide, his inexperience offering us the chance to empathize with him.

\section{Picaresque?}

Nixon writes briefly on GraceLand, situating it as a "picaresque" (66) novel. This characterization is not quite spot on. The picaresque novel is usually the account of a "carefree 
but engaging rascal" (Bedford Glossary 344). It is a chronicle of a rogue who scrapes by surviving on his or her wits and a relatively minor degree of criminal enterprise. For example, Huckleberry Finn is considered a picaresque novel because of its orphan and runaway slave protagonists' misadventures. Nixon astutely recognizes the power of the picaresque to tell the survival tales of the lowest of the low as well as examine class politics of crime through "contrasting the narrator's peccadillos with the weightier crimes that society's overlords commit and from which they are exonerated" (55). Authors who create picaros in the context of slow violence give voice to people who must improvise their way to survival on a daily basis. By comparing the picaro's informal and often illegal methods of making a living to the heinous crimes of elites, authors identify slow violence and its effects upon poor people, as well as the marginalized peoples' ingenuity in the face of oppression. Such a representation depicts poor people not as helpless masses, but as individuals who through a bricolage of approaches, survive.

For all the good work a picaresque novel can do, GraceLand is not really one. Picaros populate the slums of Lagos, Elvis' best friend, Redemption is one, but the main character is only aided by these individuals. Elvis is not a picaro because he is too naive compared to the novel's adept survivalists and because he displays too much growth during the course of the novel. As a 16 year old boy, Elvis travels the city's underground next to Redemption and connects to village life through the "King of the Beggars"' (an indigent wise man) traveling entertainment troupe. He is taught moral values by the king, his relationship with his alcoholic father improves, and he comes to some conclusions on humanity ('“most people just want to work hard, earn a living, and find some entertainment"' [280]) all of which suggests an evolution in his character. Picaros are good for depicting social conditions and class structures 
because they do not significantly change or develop (Bedford Glossary 344). Such a description fits Redemption better than Elvis. Though ostensibly committed to traveling to the U.S and attaining the class mobility it promises (Abani 26), Redemption never reaches that goal. Instead, he passes his illicit visa to Elvis observing, "America is better dan here. For you. Your type no fit survive here long'” (318). Redemption knows that his place is in Lagos (“'I be area boy, alaye. I no go fit for states'" [317]) as much as he knows that Elvis will die if he stays. Redemption's refusal of the passport is his character's rejection of change, a cementing of his character as picaro, and a further indication of Elvis' outsider status. Elvis' possession of the visa and ultimate departure for America is the final proof that he is not a Redemption or Okon type character. His sensitivity to the horrors of street life, his journey to experience as well as his escape from Lagos makes the novel more Bildungsroman than picaresque.

\section{Bildungsroman?}

Graceland is not a conventional novel of formation. It is the dark and twisted postcolonial version. It is not Oliver Twist, where the protagonist starts as an orphan in a hostile slum but learns from a host of characters and against all odds, transcends his indigent situation through a moral and economic transformation. While a place in society is hinted at and perhaps implicitly expected by the reader through Elvis' formative experiences, GraceLand is a novel in which these hopeful transformations are smashed for Elvis and the rest of Maroko through repressive government action and suffocating poverty. Abani triggers our expectations for a classic Bildung in which Elvis finds dignity and a place within society and then harshly reneges on it. 
The evaporation of Elvis' successful formation begins towards the end of the novel. As popular support for a peoples' protest against the military dictatorship builds, Elvis is scooped up by the police, tortured by the Colonel (the psychopathic head of state security) for information about the radical King of Beggars and released, half-dead, wandering homeless and starving until Okon (another savvy picaro) finds him. Later, Elvis joins Okon by necessity as a guardian for orphan beggar-children and his idea of himself as a morally upstanding person (a hard-won self-image gotten by buying beggars meals, and choosing to be a fugitive rather than participate in the Colonel's organ trade) is compromised due to the exploitative nature of the work. "Just thinking about the degradation made Elvis' skin crawl" (309). A sexual encounter with one of his pre-adolescent wards further works against his understanding of his own moral integrity. Even though it is initiated by the girl and Elvis stops the sex act before completion, his spirit is broken leaving him wondering "why his body had not cringed, why he had enjoyed it, desired more" (311). As if pointing to the protagonist's frustrated moral formation, Okon mocks Elvis for resisting, simultaneously perverting one of the most famous Bildungs of all time: “'Don't start your shit. She wants it and that's all that matters ... You go learn. We call her Oliver Twist because she no fit to get enough'" (312). At the end of the novel, the only way out of his economic and spiritual purgatory is an escape to the west.

As Ashley Dawson writes in "Surplus City," the outcome of Elvis' failed attempt to realize himself in Lagos' "constitute(s) an indictment of the system that is producing the slum" (32). When read this way, Elvis' "spacial egress," (Dawson 16) far from being a happy ending, portrays the conditions of Lagos as impossible and made that way because of governmental exploitation. GraceLand is a failed Bildung, but it does the work of demonstrating that the extreme poverty 
and oppression in Lagos precludes the possibility of survival for an individual who doesn't participate in the illegal economy with its dubious morality.

\footnotetext{
"Dose tiefs in the IMF"
}

Nixon writes, "In the long arc between the emergence of slow violence and its delayed effects, both the causes and the memory of catastrophe readily fade from view. As a result, casualties incurred often pass uncounted" ("Slow Violence"). Time is often the enemy for environmental justice groups seeking reparation or an acknowledgment of fault from international perpetrators. Referring to the chemical explosion at the Union Carbide plant in Bhopal of 1984, Nixon highlights how multinational corporations take advantage of "legalistic, geological, euphemistic" mechanisms to ensure the passage of time, hoping to take advantage of environmental degradation's low half-life on the world stage.

Through this battery of attritional dissociative mechanisms the transnational corporation seeks to wear down the environmental justice campaigns that seek compensation, remediation, and restored health and dignity. Under the cover of a variety of temporal orders, the company can hope that public memory and demands for restitution will slowly seep out of sight, vanishing with the sands of time (Slow Violence 60).

Piercing the obfuscating "dissociative mechanisms" that keep the world from identifying the parties responsible for the degrading and often fatal living conditions in the global South is a key goal for those who write of slow violence.

Mike Davis in Planet of Slums shows the share of blame neoliberal economic policies have in bringing about the global poverty illustrated in GraceLand. Following the debt crisis of 
the 1970's, third world governments including Nigeria were granted debt relief on conditionality. Specifically, that they would submit their economies to the IMF's Structural Adjustment Programs (SAPs). The conditions of these loans increased each nation's debt load and required an adoption of neoliberal economic ideology which deregulated the nation's markets, removed social safety nets, required the de-funding of agricultural subsidies, and the removal of protectionist tariffs on imports, all to facilitate competiveness in the world market and attractiveness to foreign investors (15). The removal of price control on agricultural items and tariffs on food commodities led to farmers' enhanced vulnerability to outside factors like drought, civil war, and rising interest rates (15).

Following the failure of such farms to stay productive, peasants left the countryside in droves hoping to avoid starvation, in what became a huge migration to city areas. This massive trend toward urbanization has resulted in what Davis describes as "a watershed in human history, comparable to the Neolithic and Industrial revolutions" (1): Since 2010 "the global population as a whole has become more urban and less rural" with $50.5 \%$ of the world's 7 billion people living in cities (U.N 2009 Revision of World Urbanization Prospects). The UN acknowledges that "there is little to no planning to accommodate these people or provide them with services," (qtd. in Davis 7). This lack of basic services coupled with massive urbanization sans industrial development ${ }^{5}$ leads to massive unemployment (23.9\% in Nigeria [2011 ClA Factbook]) creating the desperate situation of very poor communities on the periphery of mega cities like Nairobi and Lagos.

\footnotetext{
5 “' 'Overurbanization' . . . is driven by the reproduction of poverty, not by the supply of jobs" (Davis 16).
} 
Many of the loans issued to Nigeria in the 80's in 90's were simply stolen by the military dictatorship. General Sani Abacha is believed to have siphoned 500 million dollars (by conservative estimates) into Swiss bank accounts during the 90's (New York Times). \$14 billion were racked up during Nigeria's rule by military junta (JubileeDebtCampaign.org), left to the people and their recently democratically elected government to pay with interest. ${ }^{6}$

Through the beggar king, Abani succinctly cuts through the temporal opacities and deflected responsibility surrounding structural poverty in Lagos, laying the blame directly upon the International Monetary Fund, (IMF) The World Bank, the corrupt national elites, and "de U.S" (Abani 280). When trying to solve question of who should be blamed for Nigeria's poverty Elvis asks the King, "'But how is the World Bank responsible if we mismanage the funds they give us?"' setting off a powerful critique.

"Funds? What funds? Let me tell you, dere are no bigger tiefs den dose World Bank people. Let me tell you how de World Bank helps us. Say dey offer us a ten-million-dollar loan for creating potable and clean water supply to rural areas. If we accept, dis is how dey do us. First dey tell us dat we have to use de expertise of dere consultants, so dey remove two million for salaries and expenses. Den dey tell us dat dey consultants need equipment to work, like computer, jeeps or bulldozers, and for hotel and so on, so dey take another two million. Den dey say we cannot build new boreholes, but must service existing one, so dey take another two million to buy parts. All dis money, six million of it,

\footnotetext{
6 President Obasanjo of Nigeria speaking after the 2000 G8 summit in Okinawa: "All that we had borrowed up to 1985 or 1986 was around $\$ 5$ billion and we have paid about $\$ 16$ billion yet we are still being told that we owe about $\$ 28$ billion. That $\$ 28$ billion came about because of the injustice in the foreign creditors' interest rates. If you ask me what is the worst thing in the world, I will say it is compound interest" (Talabi).
} 
never leave de U.S. Den de use two million for de project, but it is not enough, so dey abandon it, and dey army bosses take de remaining 2 million. Now we, you and I and all dese poor people own the World Bank ten million dollars for nothing. Dey are tiefs and I despise dem-our people and dey World Bank people!" the king ranted. (280)

As we have seen, the King's rant echoes sociopolitical accounts of the failure of Bretton Woods institutions and governmental corruption in the information presented and in its direct, blunt approach. How does it avoid the silencing, disenfranchising effect which Nixon claims as a systemic side-effect of academic accounts on the subject (Nixon 66)? The reader trusts the King's voice as authentic because the novel has been building the Kings credibility throughout as a man tied to the community. He is after all a troubadour who travels the country side with his troupe, the Joking Jaguars, performing theater and song (274). He is also a poor man, yet respected in the slums of Lagos (254) as well as an activist performing songs and giving speeches against the military government and Western cultural imperialism (154). So when the King speaks didactically about exploitive lending practices, he is not doing so as an outsider. He is more an evangelizing character, teaching the radical truth about economic oppression than an academic, whose discourse rules would prevent from using un-sourced and hypothetical examples to prove a point. The King doesn't need to cite anything. His personal experience with slow violence makes him an expert on the subject of exploitation and his embedded-ness within the culture makes him believable and authentic.

GraceLand succeeds in dramatizing the community's harsh experience through realism's unique approaches to story telling. 
The effectiveness of the king's speech is dependent upon one of the many realist aesthetic techniques at work in the novel, specifically the mode's focus on the individual. This trope facilitates the creation of complex characters bearing a verisimilitude to people, allowing readers to empathize or otherwise emotionally connect with the story. The realist point of view of Maroko from the uninitiated Elvis wouldn't have the same effect on the reader if the main character wasn't as fleshed out as he is. The King's rant would similarly feel like a ventriloquist act, with the author clumsily imbuing his views upon a lifeless puppet.

GraceLand's invokes Bildungsroman but shows the impossibility of Bildung. In "The Bildungsroman and Its Significance in the History of Realism" Bakhtin describes the story of formation as of "special importance" to the realist novel (19), with traces of it occurring in "almost all important realistic novels" (24) ${ }^{7}$. GraceLand is a twisted Bildungsroman which frustrates our expectations for material and spiritual progress to be gained by the end of the Bildung, and this frustration lends itself to portraying Lagos in all its suffocating reality.

Graceland's linear approach to attributing doesn't let the reader claim ignorance of the hidden causes of poverty and inequality. The king's rant cannot be called metaphorical. Nor can Elvis' spare description of life in Lagos be taken as figurative. These traits make GraceLand an effective realist approach to dramatizing slow violence. As its success is dependent upon

\footnotetext{
${ }^{7}$ Bakhtin examines Bildungsroman exhaustively, splitting it up into 5 subtypes of which the $5^{\text {th }}$ is of most importance to him. It describes a novel in which the hero's formation is accomplished in "real historical time" (23) rather than occurring against the backdrop of a static world. Bakhtin understands this view of time and history as part of the idea that spacial change is linked to temporal change, an idea that emerges counter to the older belief that the world is already fully formed and that time is simply continued progression of natural cycles. Bakhtin gives credit to the Enlightenment for "paving the way" for this historical sense of time, (26) which is interesting to me as it shows the Bildung as we know it to be a product of the same epistemologies that gave rise to realism.
} 
depicting the desperate physical situation of marginalized communities, GraceLand is an excellent example of how the realist mode can be used to represent non-Western experience while not playing into the privileged ideological perspective of western mass culture. GraceLand writes "from the margins" (D'haen 195) using only the effective tools of realism, not its hegemonic baggage.

\section{Berji Kristin: the Margins Become the Center}

Berji Kristin is exceptional because it is completely devoted to representing the squatter community and nothing else. The introduction by translator Saliah Parker claims that Tekin based her narrative off of actual accounts of life in squatter communities that began springing up on the outskirts of Istanbul in the 1960's (Saliah 12). In this way Tekin mimics the older, indigenous oral tradition of the masal (folk/fairy tale)(13), which seems to confirm Zamora and Faris' assertion that magical realism reconnects with disrupted indigenous methods of representation (see 4 of this document). As a result the authenticity of Berji Kristin seems indisputable. Written as a world of its own (13), the Garbage Hills are directly in the center, changing places with the metropolis in the distance.

Because the community as a whole is the focus of the novel, no one character comes to dominance. There are a number of people who bear the focus of the narrative for a short period, but they usually fade into the background from chapter to chapter, leaving communitythreatening or formative events to drive the novel. These events compile throughout the course 
of the text to make up a short cultural history of the slum starting from its foundation ${ }^{8}$ to its final imagined configurations ${ }^{9}$, but because the novel views Flower Hill with such a wide lens, it is difficult to get to know any of the figures that play a part in the community. They hardly speak at all: instead an anonymous third person narration speaks from a detached (but respectful) omniscient position, encapsulating the experience of the community as it moves through time in masal style episodic chapters.

The strength of this style of narration is also its weakness. While we are kept from fully empathizing or identifying with central characters (an important part of the realist novel), the void allows the novel to keep the community as its central character. When taken as a character, the community-a term which encompasses the houses, huts, buildings, garbage as well as the people, culture-in Berji Kristin can be shown throughout its development from huts to more permanent buildings, informal to formal settlements as well social conflicts: strikes, battles with bulldozers, political campaigns, and gender politics to name a few. The episodic chapters create a piling effect with which the reader gains a gradually deeper understanding of this settlement's experience. True to magical realist form, the individual character is not separated or emphasized above the communal, reflecting the culture's priorities. It is also a little more direct than GraceLand's realism in that the reader is not asked to empathize with a character and then use

"“One winter night, on a hill where the huge refuse bins dumped the city's waste, eight shelters were set up by lantern-light near the garbage heaps" (15).

\footnotetext{
9 " The coffeehouses, empty now since the men's withdrawal from Foundation Hill, were taken over by male squatters from other neighborhoods and by workers and their bosses from the Rubbish Road repair sheds, and when the gypsies moved downhill a little from their cardboard houses, this put the finishing touches on Foundation Hill" (156).
} 
that character's experience as representative of the community. Rather, the community is always front and center in the narrative.

As faithful as Tekin is to centering the garbage hills in the narrative, the way in which Berji Kristin represents suffering in community, although often emotionally resonant, can be confusing and unproductive in terms of dramatizing the causes and effects of slow violence. Like GraceLand, Berji Kristin describes the physical degradation suffered by the people of Flower Hill, but as it is a magical narrative, its approach is a little different. Tekin's descriptions go from fairly mimetic to the obvious stretching of reality. In keeping with what we have learned about magical realism, she uses a blend of both realism and magical elements to do dramatize the arduous life of Flower Hill. The most realistic descriptions in Berji Kristin describe the polluted environment the community is forced by necessity to use and be poisoned by. The following passage describes events in which the community is angered over the factory owner's flagrant disregard for its health. His building is releasing chemical discharge into the air in the form of white particles, quickly designated as "factory snow" which makes everyone sick, killing livestock and a few small children (28). To appease the enraged community, the factory owner gives everyone a bowl of yogurt and routes his warm waste water into their village. For this he is treated like a saint, before the villagers fully understand the true nature of his "gift"

$[H]$ e flooded the neighborhood with hot bluish water in which the factory serum and medicine bottles were washed. This was a truly festive day for Flower Hill. They diverted the first jet of hot water and cemented around the channel where it flowed. . . Only Flower Hill had the good fortune to wash in blue water under snow on a summer's day. The men dragged an old truck chassis a long distance to the fountain head and from 
then on married couples took it in turns to get inside the chassis at night after intercourse and wash themselves in hot water... Before long, odd changes began to appear in those who washed in this water. The skin of some began to peel while the faces of others turned purple. Bright blue spots came out on the children's bodies and the hair of two women went white. The clothes took on a blue colour which came to be known on Flower Hill as "Squatter's Blue." (28)

This approach to representing mass community poisoning is both magical and realist, as it is extreme but believable as a non-metaphorical description of a plausible occurrence. Perhaps there is something special about chemical spills that allow us to believe that bizarre and macabre deformities, (like an entire village turning blue) are perfectly plausible, although this kind of dramatic transformation is a magic itself. But beyond the literal interpretation, reading this passage for metaphorical overtones is an equally profitable approach. The entire community is marked by this pollution-in-the-guise-of a gift, yet it is not demonstrated against like the "factory snow" that came before it nor is the fountain destroyed: it is incorporated into the Hill's daily life. Life is so precarious that even disfiguring water is still used in the community, from the washing of pots and clothes to the most intimate cleaning of married couples. The dyeing properties of the water are invasive and dehumanizing, as well as a powerful symbol. Whether or not this instance is based on fact, it tells us that the factory owner can operate with near impunity, demonstrating his power over them as well the community's desperate need for basic infrastructure.

As profitable as the metaphorical descriptions of physical hardship can be, Berji Kristin contains one passage in particular in which an attempt to depict the harsh reality goes too far 
into metaphor, lapsing into an unbelievable image which generates slippage in reader interpretation. It describes an instance in which the men of Flower Hill become permanently disabled while leaning against the wind during a particularly vicious snowstorm: “ . . that snowy night they came home with twisted backs and neck awry and fell into bed sweating. For ten days the Flower Hill men did not open their eyes from 'wind sickness'; . . the illness passed but left them with neck and shoulders even more twisted and lopsided" (34). While the previous passage grants readers an understanding of the community's oppression by economic avarice and/or apathy, this bit about the wind goes so far into the metaphorical that it's hard to understand whether the wind just blows really hard or if it is the wind but also some sort figurative representation of oppression. I suppose it could be both, but in the absence of conclusive evidence one way or another, the take-away from a passage like this is limited to pity or disbelief. Pity because the image reinforces how arduous life is on Flower Hill, or disbelief, because while the wind was shown to be a destructive, antagonistic force before (Tekin 17), its twisting of the men seems to be almost too much a departure from reality, making the text edge away from showing the community's experience in favor of some sort hyper-fantastical situation. The fantastical is not bad in and of itself, but it appears in this passage without a solid metaphorical or realist thematic connection to the community, which is dangerous. It is dangerous because its lack of believability lets the reader abstain from recognizing the community's perilous survival situation, and it is flawed because it isn't very powerful metaphorically.

Unlike GraceLand, Berji Kristin doesn't attribute its misfortunes very directly to oppressive forces outside the municipality. The factory owners are implicated, but no 
organizations which have bearing in the world outside the novel are indicted, except one and very obliquely. The people find a sign posted by municipal authorities renaming "Rubbish Road" to "Nato [sic] Ave" (36). There is much discussion over what the sign means and if it has any connection to their deformities. The people uproot it and throw it over a cliff (38), only to see it return shortly thereafter (49). This is as a close as the novel gets to naming some extra-city source responsible for Flower Hill's toxification. Berji Kristin is so focused upon the community, that it resists linking up with social scientific accounts of slum communities such as Davis' Planet of Slums ${ }^{10}$, opting instead to identify exploitive characters and practices within the community. Due to the third person omniscient narrator the novel is very adept at attributing these smaller-scale, localized abuses to abusers. Mr. Izak, the owner of an appliance factory (86), leaves town after repeated strikes in his factory but his "name remained, inscribed in the sky" (100) with the noxious refrigerator gas he pumped into the atmosphere. "He signed his name clearly in chemicals," Tekin writes (99). This passage dramatizes the pervasive violence done by Mr. Izak's factory, doing the tricky work of holding the owner accountable even when the person is no longer onsite. It bridges the spacial gap often generated in instances of slow violence when the polluter leaves but his toxic legacy remains though disconnected from his physical presence, a strategy of avoidance based on distance used by transnational corporate entities to avoid being recognized for their share of the blame (see Nixon on p. 24). We should also note that this description, while fantastical on a literal level, works metaphorically as well, showing the flexibility of magical realist tropes to create more narrative surface area for readers to connect and draw meaning from. This passage has broad possibility for interpretation which

\footnotetext{
${ }^{10}$ Incidentally Mike Davis does mention the book in passing (38).
} 
while beneficial in some ways, also opens the novel up for criticism in that through its vigorous devotion to local conditions, it does not reveal the network of "occluded relationships" (qtd. in Slow Violence 45)-such as global labor dynamics, "transnational economic pressures" (45) and interventions through Bretton Woods institutions (Slow Violence 45)-which may shape the living conditions of Flower Hill locally. In other words, the novel is too myopic in scope to reveal the structural quality of the local oppression. In my view, this criticism does not take into account the pitfalls surrounding a narrative that is overly explicit in its fingerpointing. Namely that a narrative which speaks too explicitly and polemically runs the risk of appearing artificial. As the Irish writer Eavan Boland remarks, "If a voice of a character in a fiction speaks too clearly with the anger and hindsight of an ethical view of history, then the voice may be made louder by argument but grow less convincing through being less imagined. Then both history and humanity can be sentimentalized" (qtd. in Slow Violence 52). Tekin avoids this dichotomous crisis of sentimentality-or-shortsightedness by creating a fictional community which can function as synecdoche for the many squatter communities propped up around Istanbul during the period. This allows Tekin to write about issues facing a growing segment of marginalized yet "socially significant" (13) people in Turkish society without representing an actual community, thereby reducing the opportunity for the narrative to fall into sentimentalizing actual history. The magical realist form helps distance the narrative from historical actualities while preserving the option to interpret its fantastical as clouded metaphors: references to actual occurrences and implications of global power dynamics.

Tekin's reference to NATO for example, which does not directly implicate the Western dominated power structure as an instigator of oppression, does by its inclusion invoke the 
feeling that global forces are at work in the Garbage Hills. Shortly after the windstorm which cripples the men of Flower Hill, the Nato sign is erected, causing much discussion over its meaning "One said it meant 'Armed Force', another 'Bombing'" (37). When the community's spiritual leader, Güllü Baba suggests that NATO has something to do with the men's deformity, the locals rage at the sign and more questions emerge. "Some people wanted to know in what language 'Nato' [sic] meant 'deformity' and others were obsessed by the question of why the sign didn't simply say 'deformity'. In the end the whole matter reached an impasse (37). Although it is suggested that NATO is connected with deformity, it is by no means explicitly stated. Some people in the village even doubt that it is so (38). NATO's entry into Berji Kristin is inconclusive, yet ironically productive. Through its ambiguity the reader is given a sense that global dynamics are at play in the plight of the community-why would a street in a slum be named after NATO without some causal relationship between the two? -even while that assumption is questioned. This questioning eliminates the possibility for the kind of historical sentimentality which Boland warn against, while keeping the door open for the connection the narrative implicitly suggests. Like many other ambiguous passages in Berji Kristin, two seemingly incompatible readings work side by side, creating flexible interpretations of the community's experience. Far from being unrealistic, this odd coupling portrays how difficult it is to grasp the hidden causes of oppression in these types of slum communities. To hypothesize global connection to local oppression requires study and political awareness which is not easy to come by and often suppressed, so it follows that the locals are not able to fully identify the connection between themselves and NATO. 
While Berji Kristin may not exactly "trace the 'occluded relationships'" between the international and the local, it certainly is devoted to the "close living substance"' of the community. The sign incident ends with Flower Hill's defiance. The people refuse to recognize the official "Nato Avenue," and although the sign is reposted by the authorities, Güllü Baba declared that its true name will remain in the "language pockets" of the residents, with the local "Rubbish Road" trumping the outsider "Nato Avenue" (38). This defiance is emblematic of how the novel walks the line between excessively explaining systemic "occluded relationships," and deferring on the question of their existence. Berji Kristin layers on an invocation of the global while remaining unswervingly devoted to the local.

\section{Conclusion}

Berji Kristin is a wonderful example of the effectiveness with which magical realism can represent the stark reality of slum life as well as the potential shortcomings of the form in this context. A description of a poisoned community which is too loosely metaphorical leaves the reader lost, not because he or she is intolerant of the fantastical, but because it is disconnected from the visceral experience of the poor without a clear figurative link to the community. When the image is strong in the novel, the reader doesn't have to choose between believable or fantastical: he or she can have it both ways, increasing the avenues of interpretation, doubling the opportunities for communicating the experience of slum communities.

There is no "alternate reality" (Tekdemir 44) at play in The Garbage Hills, rather a nonWestern cultural system incorporating realism to describe the unique experience of the people 
of Flower Hill. What results is a hybrid form (Bower), a bricolage which combines elements of Western and indigenous methods of cultural production to form a bridge between the two. Realism and magical realism are different tools with which authors represent the experiences of their community. Though it relies on the personal development of an individual character, realism as seen in GraceLand, does not lose the community and reflect only a western voyeuristic experience of slum living in Lagos. It uses the strength of the mode to its advantage, crafting engaging characters to reveal the oppression against them and, by association, the poor of Lagos. Realism allows GraceLand to explain more deeply the systemic dynamic of oppression against the people of Maroko without sabotaging the character's believability or sentimentalizing history. As I have said before there are certain advantages to the approach Berji Kristin takes as well, but the point is that no novel can be judged more or less effective at dramatizing an impoverished community's experience solely on the basis of mode. Realism and magical realism should be viewed as different tools of representation that supplement each other, not as strictly opposed ideologies. To criticize authors for using a literary mode on the assumption that it cannot possibly represent the chosen subject matter because of its linkage to a different cultural system doesn't take into account the figure of the author, the motivations for writing, the people being described, and every other dependent variable that must be accounted for if one wishes to make a statement on the authority and authenticity of a text. Above all, it is insufferably limiting, and if we want creative, innovative work from our authors, we should not pressure them one way or another. Instead we ought to appreciate the abilities each mode brings to the table while noting its shortcomings. We should 
ever preserve an open mind and with it the ability to have our most calcified opinions revised by a story that artfully breaks the rules. 


\section{Works Cited}

Aristotle. "Poetics." The Norton Anthology of Theory and Criticism. 2nd ed. Ed. Vincent B. Leitch et al. New York: Norton \& Company, 2010. 88-115. Print.

Abani, Chris. GraceLand. New York: Picador, 2004. Print.

Bakhtin, Mikhail. "The Bildungsroman and its Significance in the History of Realism (Toward a Historical Typology of the Novel)" Speech Genres and Other Late Essays, Ed. Caryl Emerson and Michael Holquist. Austin: University of Texas Press, 1986. Print.

Bowers, Maggie Ann. Magic(al) Realism. New York: Routledge, 2004. Print.

Buell, Lawrence. "Toxic Discourse." Critical Inquiry 24.—3 (1998): 639-665. JSTOR. Web. 1 Nov, 2012. Web.

Davis, Mike. Planet of Slums. Fairfield: Verso, 2007. Print.

Dawson, Ashley. "Surplus City: Structural Adjustment, Self-Fashioning, and Urban Insurrection in Chris Abani's GraceLand." Interventions 11.1 (2009): 16-34. Uneven Developments. Web. 11 Mar. 2013.

D'haen, Theo L. "Magical Realism and Postmodernism: Decentering Privileged Centers." Print. Magical Realism:Theory, History, Community. Ed. Lois Zamora and Wendy B. Faris. Durham: Duke UP, 1995. 191-208.

Diniejko, Andrzej. "Charles Dickens as Social Commenter and Critic" The Victorian Web. n.p: 2012. Thurs. 28 Feb. 2013.

Eagleton, Terry. "What is a Novel" The English Novel. Oxford: Blackwell, 2005. Print. "Extreme Poverty Rates Continue to Fall." Worldbank.org. The World Bank, 2 June 2010. Web. 
11 Mar. 2013. <http://data.worldbank.org/news/extreme-poverty-rates-continue-tofalls.

Ibukun, Yinka. "Rio+20 Challenge: Seeking Sanitation in the Slums of Lagos, Nigeria." The Christian Science Monitor. N.p., 12 June 2012. Web. 11 Mar. 2013. the-slums-of-Lagos<http://www.csmonitor.com/World/Africa/2012/0612/Rio-20-challenge-seekingsanitation-in-Nigeria>.

"Late Nigerian Dictator Looted Nearly \$500 Million, Swiss Say." The New York Times. N.p., 19 Aug. 2004. Web. 19 Mar. 2013. <http://www.nytimes.com/2004/08/19/world/latenigerian-dictator-looted-nearly-500-million-swiss-say-html?ref=saniabacha>.

Loomba, Ania. "Colonialism and Knowledge." Colonialism/Postcolonialism. 2nd ed. New York: Routledge, 2005. 62-82. Print.

Macaulay, Thomas B. "Minute of 2 February 1835 on Indian Education." Comp. G. M. Young. Macaulay, Prose and Poetry. Cambridge: Harvard UP, 1957. 721+. Modern History Sourcebook: Thomas Babington Macaulay (1800-1859): On Empire and Education. Fordham University, July 1998. Web. 11 Mar. 2013.

Morris, Pam. Realism. New York: Routledge, 2003. Print.

Murfin, Ross, and Supryia M. Ray. "Picaresque Novel." The Bedford Glossary of Critical and Literary Terms. 2nd ed. 2003. Print.

"Nigeria: The Debt Crisis." JubileeDebtCampaign.org. N.p., 2007. Web. 19 Mar. 2013. <http://www.jubileedebtcampaign.org.uk/Nigeria+3484.twl>.

Nixon, Rob. "Slow Violence and Environmental Storytelling." Nieman Storyboard (13 June 2011): n. pag. Niemanstoryboard.org. Web. 20 Mar. 2013. 
Nixon, Rob. Slow Violence and the Environmentalism of the Poor. Cambridge: Harvard UP, 2011. Print.

"Oil Industry Has Brought Poverty and Pollution to Niger Delta." Amnesty International. N.p., 30 June 2009. Web. 11 Mar. 2013. <http://www.amnesty.org/en/news-andupdates/news/oil-industry-has-brought-poverty-and-pollution-to-niger-delta-20090630>.

Parker, Saliha. Introduction. Berji Kristin Tales from the Garbage Hills. New York: Marion Boyars, 1996. 9-14. Print.

Talabi, Segun. "A Nigerian Approach to Islamic Banking." Businessdayonline.com. 25 Aug. 2011. Web. 18 Mar. 2013.

Tekin, Latife. Tales From the Garbage Hills. Trans. Ruth Christie and Saliah Parker. New York: Marion Boyers, 1994. Print.

United Nations. Department of Economic and Social Affairs. 2009 Revision of World Urbanization Prospects. 25 Mar. 2010. Web. 11 Mar. 2013. <unpd/wup/Documents/WUP2009_Press-Release_Final_Rev1.pdf>.

United States. Central Intelligence Agency. World Factbook: Nigeria. N.p., n.d. Web. 18 Mar. 2013.

Zamora, Lois P., and Wendy B. Faris. "Daiquiri Birds and Flaubertian Parrot(ie)s." Introduction. Magical Realism: Theory, History, Community. 2nd ed. Durham: Duke UP, 1997. 1-11. Print.

Zamora, Lois. "Magical Romance/Magical Realism: Ghosts in U.S and Latin American Fiction." Magical Realism: Theory, History, Community. Ed. Lois Zamora and Wendy B. Faris. Durham: Duke UP, 1995. 497-550. Print. 
Hawkins 36 